\title{
MECHANICAL STABILITY OF THE Cabralea canjerana SAPLINGS SUBMITED TO LIBERATION IN SECONDARY FOREST, RS, BRAZIL
}

\author{
Anna Paula Lora Zimmermann ${ }^{2 *} \odot$, Frederico Dimas Fleig ${ }^{\oplus}$ and Thomas Schroder $^{4} \odot$
}

\author{
${ }^{1}$ Received on 26.09.2018 accepted for publication on 18.02.2019. \\ ${ }^{2}$ Universidade Federal de Santa Maria, Doutora em Engenharia Florestal, Santa Maria, Rio Grande do Sul - Brasil. E-mail:<zimmermann-a@ \\ hotmail.com>. \\ ${ }^{3}$ Universidade Federal de Santa Maria, Departamento de Ciências Florestais, Santa Maria, Rio Grande do Sul - Brasil. E-mail: < dimasfleig@ \\ uol.com.br>. \\ ${ }^{4}$ Universidade Federal de Santa Maria, Programa de Pós-Graduação em Engenharia Florestal, Santa Maria, Rio Grande do Sul - Brasil. \\ E-mail: <tomaschroder@gmail.com>. \\ *Corresponding author.
}

\begin{abstract}
The liberation of trees of interest by cutting competing trees, woody vines and other lianas is a very important silvicultural practice in the management of forest species of interest present in secondary forests. Thus, we aimed to know the influence of the liberation on the mechanical stability and what dimensional height limit of C. canjerana (Vell.) Mart. saplings must have so that there is no problem of buckling of the stem after the liberation. To this end, the liberation of 105 plants of the species was carried out and the diameter and height were measured before and annually for three years after the application of the treatment. Based on the Mechanical Design Theory, a regression model was generated to know to allocation mode of the diameter and height in the analized plants. The minimum diameter for buckling and the safety factor for all trees were calculated. The liberation resulted in the buckling of the stem of five trees, all below the safety limit, that is, with a real diameter smaller than the minimum diameter to support the weight of its height. According to the regression model generated the species grows proportionally in diameter and height. However, the liberation influenced the mechanical stability of the plants liberated, making a greater increment in diameter necessary so that the trees remained standing. The results demonstrate that the dimensions of the trees to be liberated should be considered in order to avoid problems of buckling of the stem after the treatment.
\end{abstract}

Keywords: Liberation thinning; Buckling of the stem; Natural regeneration.

\section{ESTABILIDADE MECÂNICA DE PLANTAS JOVENS DE Cabralea canjerana, SUBMETIDAS À LIBERAÇÃO EM FLORESTA SECUNDÁRIA, RS, BRASIL}

\begin{abstract}
RESUMO - A liberação de árvores de interesse por meio do corte de árvores competidoras, videiras lenhosas e outras lianas é uma prática silvicultural muito importante ao manejo florestal de espécies de interesse comercial presentes em florestas secundárias. Diante disso, nós objetivamos conhecer a influência na estabilidade mecânica e qual o limite dimensional de altura que as plantas de $\boldsymbol{C}$. canjerana devem possuir para que não haja problemas de flambagem do fuste após a liberação. Para isto, foi realizada a liberação de 105 plantas da espécie, que tiveram seu diâmetro e altura medidos antes e anualmente por três anos após a aplicação do tratamento. Baseado na Teoria do Design Mecânico, foi gerado um modelo de regressão para conhecer o modo de alocação de diâmetro e altura nas plantas analisadas. O diâmetro mínimo para flambagem e o fator de segurança foram calculados para todas as plantas. A liberação resultou na flambagem do fuste de cinco árvores, todas com baixo fator de segurança, ou seja, com diâmetro real menor que o diâmetro mínimo para suportar o peso de sua altura. De acordo com o modelo de regressão gerado, a espécie cresce proporcionalmente em diâmetro e altura. Entretanto, a liberação influenciou a estabilidade mecânica das plantas liberadas, fazendo com que um incremento maior em diâmetro fosse necessário para que as plantas permanecessem em pé. Os resultados demonstram que as dimensões das árvores a serem liberadas devem ser consideradas para evitar problemas de flambagem do fuste após a aplicação do tratamento.
\end{abstract}

Palavras-Chave: Desbaste de liberação; Flambagem do fuste; Regeneração natural.

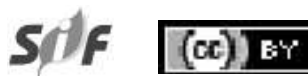

Revista Árvore 2019;43(2):e430203

http://dx.doi.org/10.1590/1806-90882019000200003 


\section{INTRODUCTION}

Due to their history of occupation, the forests of the South of Brazil were replaced over time by agricultural areas. However, the abandonment of these areas is responsible for the large percentage of secondary forests currently found in this region (Vibrans et al., 2012). According to these authors, in the state of Santa Catarina, for example, only $5 \%$ of the forests have characteristics of primary or mature forests.

Due to regional differences in patterns of disturbance and use of land and resources there is currently a considerable ambiguity in the concept of secondary forest. According to Chokkalingan and Jong (2001), secondary forests are those forests that regenerate in one place after the human or natural impacts. These forests present differences in the structure and composition of species in relation to primary forests, mainly due to the high density of pioneer species, especially when the secondary succession process is more recent.

However, in the secondary forests of the state of Rio Grande do Sul, it is common to find adult trees of the secondary species that need shade for their development in your initial and young phase (Callegaro et al., 2017). This demonstrates the advanced level of succession in these areas, with canopy formed by pioneer species, able of creating conditions for the establishment of secondary species. By the advanced level of succession and development of the species present in these forests, they often present greater growth in biomass than they do in the primary forests (Vaccaro et al., 2012).

The canopy formed by the establishment of the pioneer species, together with the presence of seed trees of secondary species, creates conditions for the recruitment of species from different sociological groups (Finegan, 1996; Hughes et al., 2012; Miao et al., 2013). This accelerating the regeneration rate (Sandor and Chazdon, 2014) increasing and the diversity of the forest and the density of the commercial secondary species, as Cabralea canjerana.

However, the succession process also offers favorable conditions for the growth of pioneer species such vines and other lianas (Esquivel et al., 2008). These species affect the establishment and development of species of commercial interest, by the rapid closure of the canopy and competition for light, water and nutrients (Ortega-Pieck et al., 2011).
According to Tabarelli and Mantovani (1999), the management of secondary forests becomes complex because species need different light intensities, and may vary during their life cycle (Dupuy and Chazdon, 2006; Davidson et al., 2002). The regulation of the density of the desirable and invasive species can be done by the balance of incident solar radiation (Gerwing and Vidal, 2003) through a method called liberation (van Kuijk et al., 2014).

The liberation of competing trees is a technique used to promote the growth of species of interest that are still immature or under competition (Schneider, 2008), but leaves them more susceptible to the actions of external forces such as wind. The liberation stimulates the growth of individual trees by decreasing competition with the removal of neighboring trees (van Kuijk et al., 2014). This method is very suitable for young populations, where competition for light and nutrients is more intense (Oliver and Larson, 1990).

However, according to some authors, liberation cuts does not always have the desired effect on the population (Otsamo, 2000; Chapman et al., 2002). Milne (1991) concluded that there is a relationship between planting density and wind speed, with high densities decreasing wind action on trees, reducing deflection and oscillations on the stem. An option to reduce the impact of the liberation would be the application of pre-liberation cuts, which gradually reduce competition, increasing tree vigor and wind resistance (Graham et al., 1999).

Among the unwanted effects is the instability of the stem of the liberated trees. This is because the trees are exposed to a distinct condition of which were acclimatised, of greater susceptibility to the action of external forces or because they do not have proportional dimensions between height and diameter. When there is no dimensional equilibrium between the supporting structures (diameter) and the aerial part (height), the plant loses its stability and a phenomenon known as buckling of the stem occurs. This phenomenon has been investigated by several authors (Niklas, 1995; Sterck and Bongers, 1998; Jaouen et al., 2007; Watari et al., 2014) and differentiates from tree tipping because in this case the root is not removed and exposed; with only the inclination of the stem towards the ground occurring.

Revista Árvore 2019;43(2):e430203 
To minimize the risks of buckling, the plant must have a minimum diameter capable of supporting its own weight (Mcmahon, 1973). The mechanical stability of the trees can be evaluated by the safety factor, given by the ratio between the actual diameter and the critical buckling diameter (Sposito and Santos, 2001).

Another form of evaluation is through the analysis of the relation between the diameter and the height of the stem. The allometric relationship is one of the most important relationships in forest science (Finger, 2006), and it is able to reflect the architecture of the tree and the proportion of investment of growth in height in relation to growth in diameter.

Given the importance of the liberation technique for the management of forests and secondary species, this work sought to analyze the dimensional limits required for young plants of $C$. canjerana to be liberated without problems of buckling of the stem.

\section{MATERIALS AND METHODS}

The study area is a fragment of the secondary Decidual Seasonal Forest, located in the Central Region of Rio Grande do Sul, Brazil (29³7'40'S and $\left.53^{\circ}, 36^{\prime} 54^{\prime \prime} \mathrm{W}\right)$. According to the classification of Köppen, the climate of the site is of type Cfa, humid subtropical, with average annual temperature of $18^{\circ} \mathrm{C}$ and average annual precipitation of $1700 \mathrm{~mm}$ (Heldwein et al., 2009; Alvares et al., 2013). The soils are of the Neosols type, shallow and with visible rock outcrops (Embrapa, 2006).

In the past, the area was used for grazing. About 25 years ago, the area was isolated and natural regeneration formed a sparse canopy with approximately 6 meters in height. In this area, 211 plants of the canjerana were measured. The diameter was measured at $10 \mathrm{~cm}$ from the soil (d), because they were natural regeneration plants, with a digital caliper; and total height (h) with tape measure and hypsometer. These measurements occurred prior to liberation.

The liberation was done by shallow cutting in two continuous areas with $225 \mathrm{~m}^{2}$ and $525 \mathrm{~m}^{2}$, totalizing $750 \mathrm{~m}^{2}$ of the area liberated. In these points all the trees of other species other than canjerana, woody vines and other lianas were liberated (Zimmermann, 2018). In the rest of the area the original vegetation was maintained as a control treatment.
The effect of liberation cuts on plant stability was monitored annually after three years (2013-2016), with plant diameter and height remeasured annually. The Tukey test (5\% probability of error) was used to verify differences in diameter and height between the plants groups (liberated standing, liberated buckled and not liberated).

In order to understand the reasons that led to the buckling of some trees, this work was based on the mechanical design theory (Mcmahon, 1973; Sposito and Santos, 2001). In order to know the mode of resource allocation of $C$. canjerana in the young phase, a regression model was generated between the diameter (dependent variable) and the total height (independent variable). The equation that expresses the allometric relations between plants is given by $\mathrm{y}=\mathrm{a} \cdot \mathrm{x}^{\mathrm{b}}$, where $a$ and $b$ are parameters derived from linear regression and $\mathrm{x}$ is a diameter and $\mathrm{y}$ is a height (Sposito and Santos, 2011).

An equation was generated shortly after liberation and three years after the treatment application. The linear regression was carried out in the statistical package SAS version 9.3 (SAS, 2004). The angular coefficient (b1) was used to determine which model of mechanical design proposed in the literature best fits the data set analyzed.

The critical diameter for buckling was calculated by the formula $d_{\text {crit }}=0,0011 . \mathrm{h}^{1,5}$ ( $\mathrm{d}$ and $\mathrm{h}$ in centimeters) (King, 1981). The safety factor was given by the ratio $d / d_{\text {crit }}$, where $d$ is the current diameter and $d_{c r i t}$ is the minimum diameter calculated.

\section{RESULTS}

The liberation cuts were realized in 105 trees of the $C$. canjerana, and immediately after the liberation cuts, five trees presented buckling of the stem $(4.8 \%)$. The mean diameter and height of the trees that remained standing after liberation were similar to the values of the trees that were not liberated, demonstrating a homogeneity of plants in the area (Table 1). It is observed, however, that the trees that presented buckling had heights much superior to the total average of the population soon after the application of the treatment.

The model generated from the regression analysis for the whole dataset was $\log d=-1.87003+1.02269$. $\log h$. The safety factor, given by the ratio between

\section{Revista Árvore 2019;43(2):e430203}


the actual diameter of the tree and the critical diameter, demonstrates that most of the plants of $C$. canjerana had a real diameter greater than the critical diameter calculated to support their own weight before liberation (Figure 1a). However, all plants that presented buckling after liberation were below the safety limit; that is, they had a real diameter smaller than the critical diameter (Figure 1a).

Trees up to one meter height seem to maintain their growth with greater stability, investing more in growth in diameter than in height. From this point, it is noticed that there is a decrease in the allocation of resources in support structures, greater growth in height and consequently reduction of the safety factor, being this fact more clearly noticed after two meters in height. Because the canopy is relatively low, taller trees are already brighter, so a greater investment in height occurs as an attempt to reach the top of the canopy.

Three years after the liberation, the geometric similarity model remained the one that best explains the form of allocation of the resources of the studied population. However, the value of the model varied three years after the application of the forest management technique, with reduction of the angular coefficient (logd $=-0.8939+0.6493 . \log h)$, demonstrating that in order to remain standing, the liberated plants required a greater increase in diameter when compared to those that were not liberated.

In other words, the rate of increase between height and diameter did not remain the same with the passage of time, requiring a greater increase in diameter in relation to the increase in height after the liberation so that the trees remained standing. This disproportionality is evidenced when one observes the annual behavior of the safety factor after the liberation (Figure 1b, 1c and 1d).
It is observed that in the first two years, the liberated plants increased their critical diameter for buckling, consequently increasing their safety factor (Figure 1b).

Thus, the influence of the liberation on the relation $\mathrm{h} / \mathrm{d}$ of the trees with the passage of time is also observed. The need for trees to become more stable, with greater diameter increase in the first year after liberation, made them less slender, decreasing their $\mathrm{h} / \mathrm{d}$ ratio (Figure $2 \mathrm{~b}$ ). This difference is more evident over time. Three years after the liberation cutts, liberated trees showed lower $\mathrm{h} / \mathrm{d}$ relationship than not liberated trees (Figure $2 \mathrm{~d}$ ).

The increase in the number of the plants with a diameter smaller than their critical diameter on and two year after the liberation can be explained by this. As the trees were already acclimated to the new condition and had already increased enough diameter to become more stable in the first year after the liberation, they continued to grow again in height and began to maintain their diameter close to the critical diameter of buckling.

Based on the highest value of the determination coefficient, the model that best fit the height-diameter ratio of the species in the young phase was $h=70.255$. $d^{0,8479}$, which showed $\mathrm{R}^{2}$ equal to 0.8815 . It is observed that there is a greater variation in the $\mathrm{h} / \mathrm{d}$ ratio up to $1 \mathrm{~cm}$ of diameter, where trees with heights varying from 30 to 80 centimeters, approximately, can be found (Figure 3).

The dotted line, which represents the critical height supported by a given diameter, proposed by King (1981), shows that the great majority of the plants analyzed had heights smaller than their diameter was able to withstand. However, plants which presented problems of buckling in the stem are above the critical line, since they had height greater than the one supported by their diameter, as already discussed above.

Table 1 - Descriptive statistics for diameter and total height of the Cabralea canjerana trees liberated and not liberated in a secondary forest soon after the application of the treatment, RS, Brazil.

Tabela 1 - Estatística descritiva do diâmetro e altura total de árvores de Cabralea canjerana liberadas e não liberadas em floresta secundária logo após a aplicação do tratamento, RS, Brasil.

\begin{tabular}{cccccccc}
\hline Sample & \multicolumn{5}{c}{ Variable } \\
\hline & $\mathrm{N}$ & $\mathrm{d}_{\min }$ & $\mathrm{d}_{\text {mean }}$ & $\mathrm{d}_{\max }$ & $\mathrm{h}_{\min }$ & $\mathrm{h}_{\operatorname{mean}}$ \\
\hline Not-liberated & 106 & 0,3 & $1,8 \mathrm{a}$ & 4,8 & 30,0 & $114,7 \mathrm{a}$ & 402,0 \\
Liberated - standing & 100 & 0,5 & $1,8 \mathrm{a}$ & 4,5 & 39,0 & $117,7 \mathrm{a}$ & 335,0 \\
Liberated - buckled & 5 & 1,9 & $2,8 \mathrm{a}$ & 4,1 & 174,0 & $259,2 \mathrm{~b}$ & 392,0 \\
\hline
\end{tabular}

In which: n: number of observations; dmin: minimum diameter (cm); dmean: mean diameter $(\mathrm{cm})$; dmax: maximum diameter (cm); hmin: minimum total height (cm); hmean: average total height $(\mathrm{cm})$; hmax: maximum total height $(\mathrm{cm})$. Averages with the same letter do not have statistical differences at $5 \%$ probability of error by Tukey test.

Revista Árvore 2019;43(2):e430203 

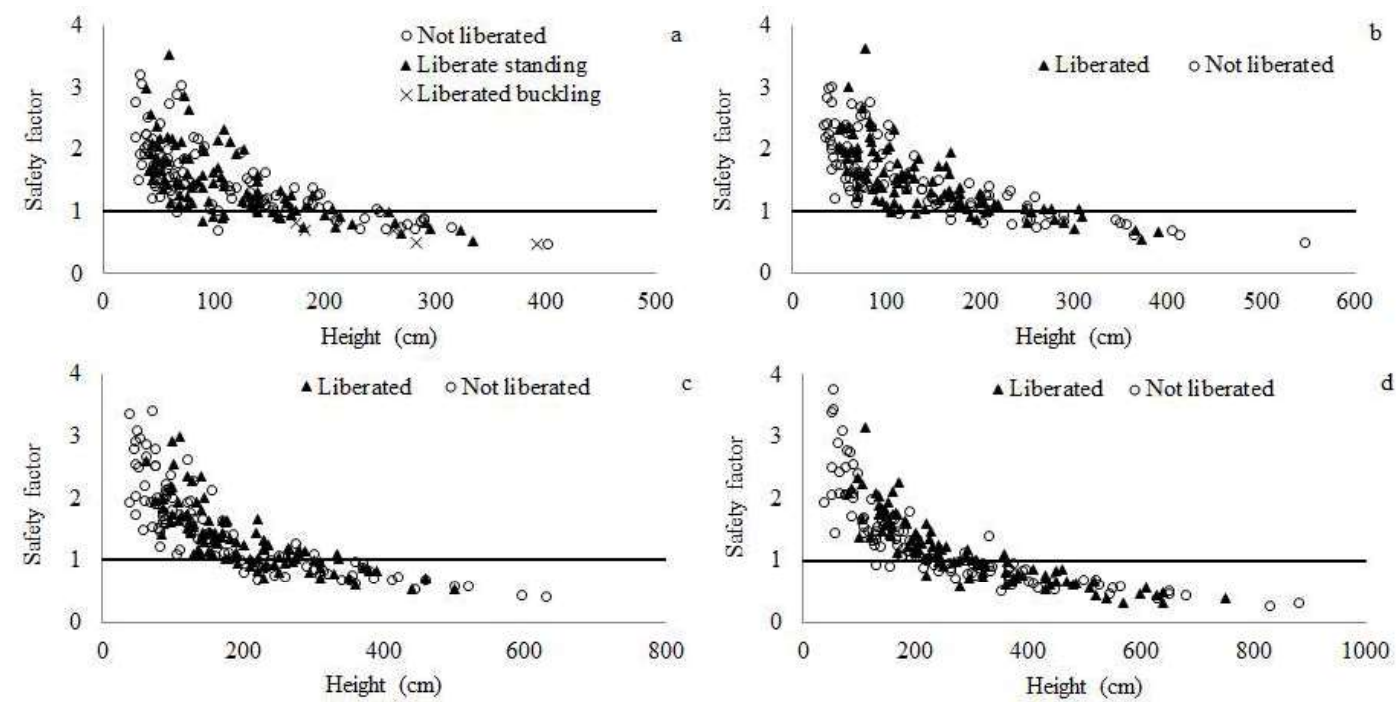

Figure 1 - Safety factor (d/dcrit) of C. canjerana saplings immediately after the liberation (1a), and one, two and three years after the liberation (1b, 1c and $1 \mathrm{~d}$, respectively).

Figura 1 - Fator de segurança (d/dcrit) de árvores jovens de Cabralea canjerana antes da liberação (1a), e um, dois e três anos após a liberação (1b, lc e ld, respectivamente).
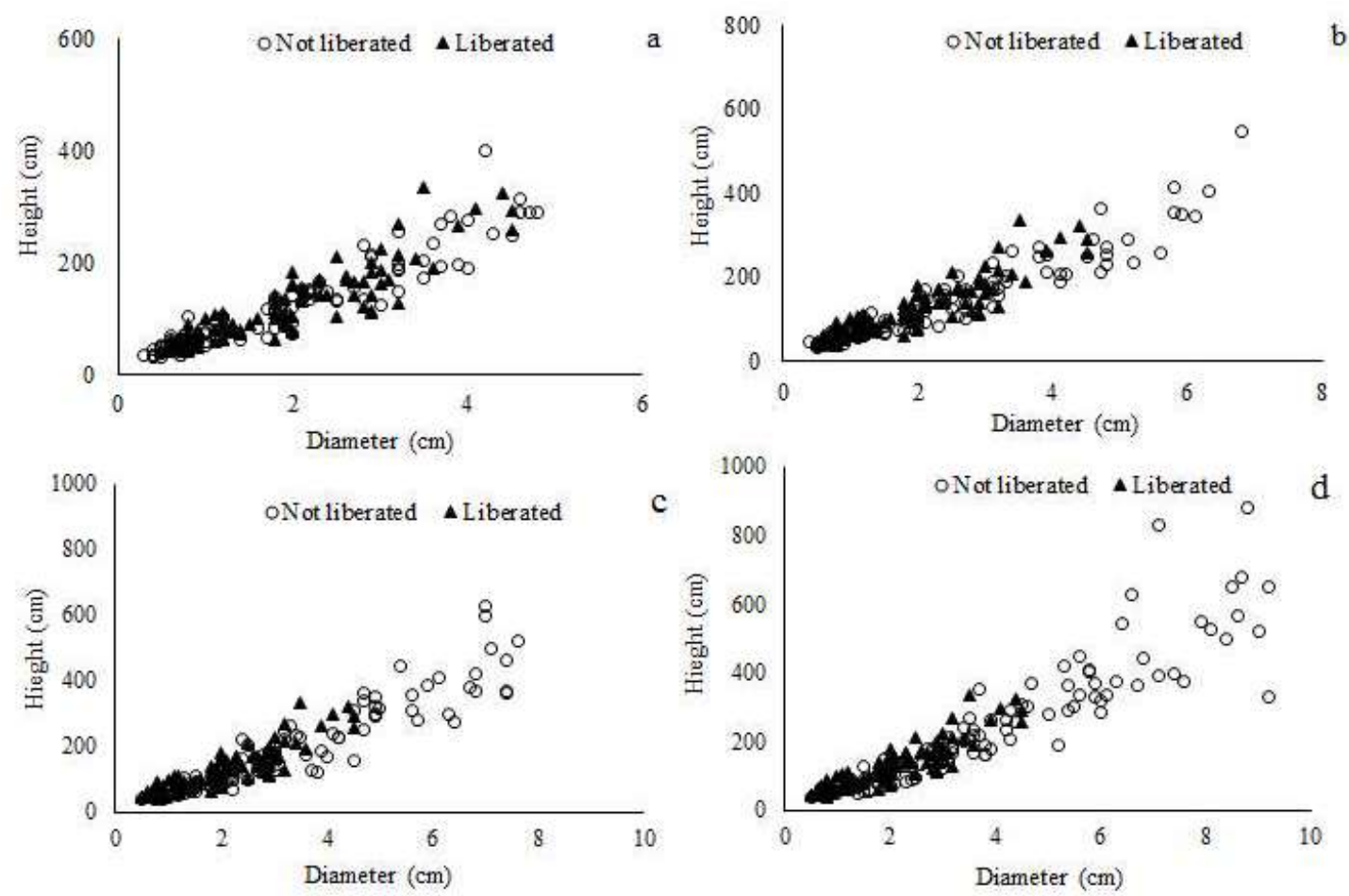

Figure 2 - Relationship height-diameter of the not liberated and liberated trees of $C$. canjerana before (a) and one, two and three years after a liberation (b, c and d, respectively).

Figura 2 - Relação altura-diâmetro de árvores não liberadas e liberadas de C. canjerana antes (a) e um, dois e três anos após a liberação (b, c e d, respectivamente). 
The coefficients of the equation proposed to calculate the critical diameter for buckling were redefined according to the values of height and diameter of the individual which is closest to the line given by the formula dcrit $=0.0011 \cdot h^{1,5}$. Thus, the equation that best explains the relationship between height and critical diameter of $C$. canjerana trees is $d c r i t=0.00091 . h^{1,5}$, which shows that this species is able to withstand a higher height for the same diameter without deflection of the stem.

\section{DISCUSSION}

The buckling stem of the 5 trees immediately after the liberation demonstrate that shows that these trees already had unstable stems due to the disproportionality of the growth between diameter and height. Possibly, these trees were only standing because they were being supported by the neighboring trees.

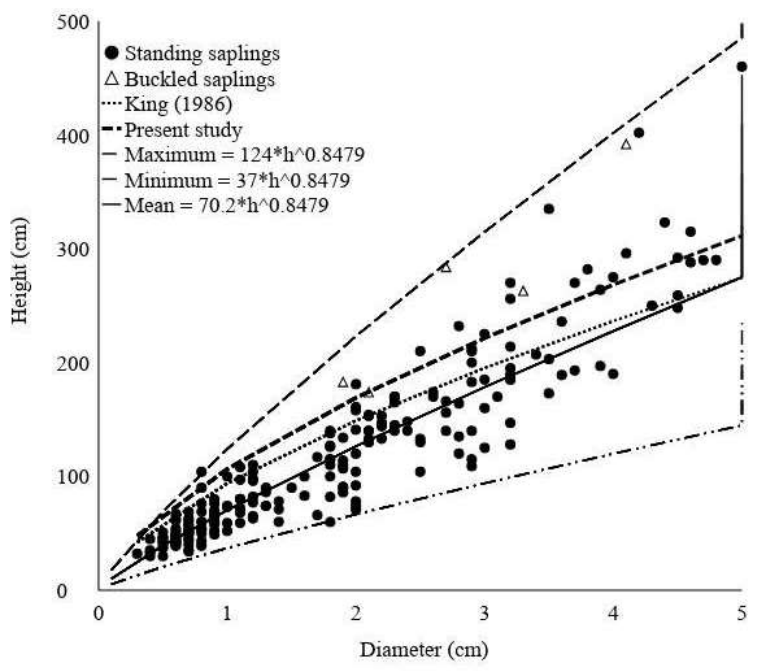

Figure 3 - Relationship height-diameter for Cabralea canjerana saplings, in a fragment of a deciduous seasonal forest, in Rio Grande do Sul, Brazil, immediately after the liberation. The solid line shows the midpoints of this relationship. The dotted line represents the critical height limits for buckling according to King (1981) and the dashed line represents the redefined limits for the species.

Figura 3 - Relação altura-diâmetro de árvores jovens de Cabralea canjerana, em fragmento de floresta estacional decidual, no Rio Grande do Sul, Brasil, imediatamente após a liberação. A linha sólida mostra os pontos médios desta relação. A linha pontilhada representa os limites críticos de altura para a flambagem de acordo com King (1981) e a linha tracejada representa os limites redefinidos para a espécie.
According to the angular coefficient and its confidence interval, the relation between the diameter and the height of $C$. canjerana frames the species in the mechanical design model of geometric similarity (Norberg, 1988). This means that trees have an isometric growth between supporting structures and growth strategies, that is, there is a proportional growth between diameter and height (1-1).

For natural regeneration trees as it is the case, this model is valid since trees are not under constant stress from the wind and there is no need for greater allocation of resources for supporting structures (diameter). Silva et al. (2009) found similar values for the height exponent by analyzing understorey trees and commented that trees in this condition tend to allocate resources for greater light uptake, as suggested by Osunkoya et al. (2007).

Another explanation for this model is given by Niklas (1995) and Furtado (2005), who suggest that isometric growth is expected early in the plant cycle, while elastic similarity and constant stress models are expected in adulthood. These differences in the mechanical design according to age or succession stage were also observed by Alves and Santos (2002), O'Brien et al. (1995) and Bohlman and O'Brien (2006). According to Vanninen and Mäkelä (2000), as competition for light increases, plants become more etiolated, resulting in greater carbon allocation at the height of shaded trees, preventing them from being overtaken by their competitors.

Analyzing the allometric relationships of eight species of the genus Cecropia, Sposito and Santos (2001) also observed a decrease in the safety factor as height increased in most species. Species of this genus, as well as $C$. canjerana, also appear to maintain a higher diameter growth rate in the early stages of development.

There is still no consensus definition on the relationship safety factor/succession group. What should be taken into account is the adaptation of the species in the place of its development since species of different tolerances to shade presented the same standard for the safety factor (Sterck and Bongers, 1998). What can be evidenced in this case is that since $C$. canjerana is a species of tolerant behavior (Zimmermann, 2014), and needs a stimulus of

Revista Árvore 2019;43(2):e430203 
luminosity to increase its rate of growth in height. The plants take advantage of the maintenance period in the shade to allocate resources in diameter, especially at the beginning of their life cycle.

According to King et al. (2009), in the period of less competition for light, the species in the understory tend to increase their safety factor, since they do not need higher investments in height to reach the canopy and thus accumulate more biomass in the supporting structures.

According to Niklas (1994), for the same mass, thinner trees are exposed to a higher level of compressive stress on their stem. In their study, Watt et al. (2006) hypothesize that trees are capable of detecting and responding to higher levels of stress, producing new wood with higher modulus of elasticity, both to reduce stem stress and to increase resistance to buckling.

The formula developed by King (1981) and based on the model of elastic similarity proposed by McMahon (1973) has been criticized over time for its generality. The variation of wood density between species and also along the stem (Wiemann and Williamson, 1989) was not considered by the proposed formula. In addition, Sposito and Santos (2001) also criticize it for the fact that the deduction of the formula assumes that the modulus of elasticity of the species is constant, standing approximately at $105 \mathrm{kgf} / \mathrm{m}^{2}$, considered low by Niklas (1992) who considered that for the majority of the woody species this value would be close to $108 \mathrm{kgf} / \mathrm{m}^{2}$.

\section{CONCLUSION}

The liberation resulted in the buckling of five C. canjerana trees $(4.8 \%)$, all of them with a critical diameter smaller than necessary to support the weight of their height.

Cabralea canjerana in the natural regeneration phase develops according to the mechanical design model of geometric similarity, with proportional investment in the growth rate in diameter and height.

The liberation influenced the model coefficients and the safety factor behavior over time, due to the need for the plants to become more stable. However, the mechanical design model remained the one that best explains the resource allocation in the plants analyzed after three years of evaluation.

For a same diameter, $C$. canjerana saplings seem to support a height higher than the one proposed in the literature, where the redefined equation that best explains this relation is dcrit $=0.00091 . h^{1,5}$.

Due to the importance of the liberation as a technique to increase the growth rates in secondary forests, studies like this should be repeated with other species of interest, in order to know the dimensional limits for the application of this technique without damages to the mechanical stability of the trees.

\section{REFERENCES}

Alvares CA, Stape JL, Sentelhas PC, Gonçalves JLM. Modeling monthly mean air temperature for Brazil. Theoretical and Applied Climatology. 2013;113:407-27.

Alves LF, Santos FAM. Tree allometry and crown shape of four tree species in Atlantic rain forest, south-east Brazil. Journal of Tropical Ecology. 2002; 18:245-60.

Bohlman S, O'Brien S. Allometry, adult stature and regeneration requirement of 65 tree species on Barro Colorado Island, Panama. Journal Tropical Ecology. 2006;22:123-36

Callegaro RM, Araújo MM, Longhi SJ, Andrzejewski C, Turchetto F, Gomes DR. Fitossociologia e fatores ecológicos condicionantes da vegetação em uma floresta estacional na região central do Rio Grande do Sul, Brasil. Iheringia, Série Botanica. 2017;72:33-43.

Chapman CA, Chapman LJ, Zanne A, Burgess MA. Does weeding promote regeneration of a indigenous tree community in felled pine plantations in Uganda? Restoration Ecology. 2002;10(2):408-15.

Chokkalingan U, Jong WD. Secondary forest: a working definition and typology. International Forestry Review. 2001;3(1):19-24.

Davidson R, Mauffette Y, Gagnon D. Light requirements of seedlings: a method for selecting tropical trees for plantation forestry. Basic Applied Ecology. 2002(3):209-20.

Dupuy JM, Chazdon RL. Effects of vegetation cover on seedlings and saplings dynamics in secondary tropical wet forests in Costa Rica. Journal Tropical Ecology. 2006(22):65-76.

\section{Revista Árvore 2019;43(2):e430203}


Empresa Brasileira de Pesquisa Agropecuária Embrapa. Centro Nacional de Pesquisa de Solos. Sistema brasileiro de classificação de solos. Rio de Janeiro: 2006. 306p.

Esquivel MJM, Harvey CA, Finegan B, Casanoves F, Skarpe C. Effects of pasture management on the natural regeneration of neotropical trees. Journal of Applied Ecology. 2008:45:371-80.

Finger CAG. Biometria florestal. Santa Maria: Universidade Federal de Santa Maria; 2006.

Finegan B. Pattern and process in neotropical secondary rain forests: the first 100 years of sucession. Trends Ecology Evolution. 1996;11:119-24.

Furtado GA. Estrutura de uma população de Esenbeckia leiocarpa Engl. (Rutaceae) numa Floresta Estacional Semidecídua no Sudeste do Brasil [dissertação]. Campinas: Universidade Estadual de Campinas; 2005.

Gerwing JJ, Vidal E. Abundância e diversidade de espécies de cipó oito anos após seu corte e exploração de madeira numa floresta na Amazônia Oriental. In: Vidal E, Germing JJ, organizadores. Ecologia e manejo de cipós na Amazônia Oriental. Belém: Imazon; 2003. p.25-34.

Graham RT, Harvey AE, Jain TB, Tonn JR. The effects of thinning and similar stand treatments on fire behavior in western forests. Gen. Tech. Rep. PNW-GTR-463. Portland: USDA Forest Service, Pacific Northwest Research Station; 1999. 27p.

Heldwein AB, Buriol GA, Streck NA. O clima de Santa Maria. Ciência \& Ambiente. 2009;38:43-58.

Hughes RF, Uowolo AL, Togia TP. Recovery of native forest after removal of an invasive tree, Falcataria moluccana, in American Samoa. Biological Invasions. 2012;14:1393-413.

Jaouen G, Alméras T, Coutand C, Fournier M. How to determine sapling bucklings risk with only a few measurements. American Journal of Botany. 2007;94(10):1583-93.

King DA. Tree dimensions: maximizing the rate of height growth in dense stands. Oecologia. 1981;51:351-6.
King DA, Davies SJ, Noor NSM. Trees approach gravitational limits to height in tall lowland forests of Malaysia. Functional Ecology. 2009;23(2):284-91.

van Kuijk M, Anten NPR, Oomen RJ, Schieving F. Stimulating seedling growth in early stages of secondary forest sucession: a modeling approach to guide tree liberation. Frontiers in Plant Science. $2014 ; 5: 345$

Mcmahon T. Size and shape in biology. Science. 1973;179:1201-4.

Miao N, Liu S, Shi Z. A review of ecological effects or remnant trees in degraded forest ecosystems after severe disturbances. Shengtai Xuebao. Acta Ecologica Sinica. 2013;33:3889-97.

Milne R. Dynamics of swaying of Picea sitchensis. Tree Physiology. 1991;9(3):383-99.

Niklas KJ. Plant biomechanics, an engineering radient to plant form ans function. Chicago: University of Chicago Press: 1992.

Niklas KJ. Plant allometry-the scaling of form and process. Chicago: University of Chicago Press; 1994.

Niklas KJ. Size-dependent allometry of tree height, diameter and trunk taper. Annals of Botany. 1995;75:217-27.

Norberg RA. Theory of growth geometry of plants and self-thinning of plant populations: geometric similarity, elastic similarity, and different growth modes of plant parts. American Naturalist. 1988;131:220-56.

O'Brien ST, Hubbell SP, Spiro P, Condit R, Foster RB. Diameter, height, crown, and age relationships in eight neotropical tree species. Ecology. 1995;76(6):1926-39.

Oliver CD, Larson BC. Forest stand dynamics. New York: McGraw-Hill; 1990.

Ortega-Pieck A, López-Barrera F, Ramírez-Marcial N, García-Franco JG. Early seedling establishment of two tropical montane cloud forest tree species: the role of native and exotic grasses. Forest Ecology Management. 2011;261:1336-43. 
Otsamo R. Early development of three planted indigenous tree species and natural understorey vegetation in artificial gaps in an Acacia mangium stand on an Imperata cylindrical grassland site in South Kalimantan, Indonesia. New Forest. 2000;19:51-68.

Osunkoya OO, Omar-Ali K, Amit N, Dayan J, Daud DS, Sheng TK. Comparative height-crown allometry and mechanical design in 22 tree species of Kuala Belalong Rainforest, Brunei, Borneo. American Journal of Botany, 2007;94(12):1951-62.

Sandor ME, Chazdon RL. Remnant trees affect species composition but not structure of tropical second-growth forest. Plos One. 2014;9(1):e83284

SAS Institute. The SAS System for Windows. Cary: 2004.

Schneider PR. Introdução ao manejo florestal. Santa Maria: UFSM; 2008

Silva SC, Cerezini MT, Santos CF, Barbosa J, Mendonça AH. Modelos alométricos como preditores das estratégias de alocação de recursos em árvores emergentes e de subdossel. Prática da pesquisa em Ecologia da Mata Atlântica. Programa de Pós-Graduação em Ecologia, Universidade de São Paulo; 2009.

Sposito TC, Santos FAM. Scaling of stem and crown in eigth Cecropia (Cecropiaceae) species of Brazil. American Journal of Botany. 2001;88:939-49.

Sterck FJ, Bongers J. Ontogenetic changes in size, allometry, and mechanical design of tropical rain forest trees. American Journal of Botany. 1998;85(2):266-72.

Tabarelli M, Mantovani W. A regeneração de uma floresta tropical montana após corte e queima (São Paulo, Brasil). Revista Brasileira de Biologia. 1999;59(2):239-50.
Vaccaro S, Wojciechowski JC, Finger CAG. Dinâmica do crescimento e produção em florestas secundárias. In: Schumacher MV, Longhi SJ, Brun EJ, Kilca RVA, organizadores. Floresta Estacional Subtropical: caracterização e ecologia do rebordo do Planalto Meridional. Santa Maria: Pallotti; 2012. p.171-94.

Vanninen P, Mäkelä A. Allocation of growth between needle and stemwood production in Scots pine (Pinus sylvestris L.) trees of different age, size, and competition. Tree Physiology. 2000;8:527-33.

Vibrans, AC, Lingner DV, Gasper AL. Considerações finais e recomendações. In: Inventário florístico florestal de Santa Catarina, diversidade e conservação dos remanescentes florestais. Blumenau: FURB; 2012. v.1. p.333-6.

Watari R, Nagashima H, Hirose T. Stem extension and mechanical stability of Xanthium canadense grown in an open or in a dense stand. Annals of Botany. 2014;114(1):179-90.

Watt MS, Moore JR, Façon J-P, Downes GM, Clinton PW, Coker G et al. Modelling environmental variation in young's modulus for pinus radien and implications for determination of critical buckling height. Annals of Botany.2006;98(4):765-75.

Wiemann MC, Williamson GB. Wood specific gravity radients in tropical dry and montane rain forest trees. American Journal of Botany. 1989;76:924-8.

Zimmermann APL. Dispersão efetiva e padrão espacial da regeneração natural de Cabralea canjerana (Vell.) Mart. [dissertação]. Santa Maria: UFSM; 2014.

Zimmermann APL. Subsídios para o manejo da regeneração natural de Cabralea canjerana (Vell.) Mart. em floresta secundária, RS. [tese]. Santa Maria: UFSM; 2018. 